\title{
THE BLACK RHINOCEROS IS BROUGHT BACK TO RUANDA
}

\author{
By J. Haezaert \\ Conservator of the Kagera National Park
}

Thanks to the protection afforded it by the Belgian Government, the northern race of the white, or square-lipped rhinoceros, Ceratotherium simum cottoni, is increasing in the Garamba National Park of the Belgian Congo. This park was specially created in 1938 to preserve the species, whose numbers there were down to about a hundred individuals. They now probably approach 1,000. But the story of the black rhinoceros, Diceros bicornis, is very different. Once common in the savannahs of Katanga, but now exterminated there, it used also to exist in the east of Ruanda, notably in what is now the Kagera National Park. So, in 1958, bearing in mind its success with the white rhinoceros, the National Parks of the Belgian Congo decided to try to reintroduce the black rhinoceros into Kagera. This rhinoceros is still not rare in some parts of Tanganyika Territory, especially in Karagwe district, but that country is separated from the Kagera Park in Ruanda by the River Kagera itself.

The game warden of Tanganyika, Mr. G. H. S. Swynnerton, unhesitatingly agreed to the transfer of six young rhinoceroses. But a licence alone is not enough ; it still has to be put into execution, and the capture and transport of an animal the size of a rhinoceros is not done without difficulty.

The first idea was to capture the young rhinoceroses in pits dug on paths leading to drinking places, but this had to be abandoned because the young black rhinoceros, unlike the white, walks behind its mother, not in front of her. In the meantime, an American scientific mission from Florida was working hard to perfect an anaesthetic based on crystallized nicotine salicylate, but although this method had proved effective for antelopes and for deer, rendering them unconscious for about 20 minutes, it had not succeeded with animals the weight of a young rhinoceros. So the President of the National Parks Institute sent one of his wardens to Tanganyika, both to study the habits and behaviour of the black rhinoceros and to try to make an arrangement with a professional trapper of large mammals. After consulting several such people, the Institute's choice fell upon Tanganyika Game, Ltd., of Arusha, whose head was Mr. W. de Beer, a trapper with forty-seven years experience and with great knowledge and love of animals. The agreement was concluded 
in June. As operations were to start in July there was no time to lose, for enclosures had to be built both at Karagwe, where the rhinoceroses were to be caught, and on the banks of Lake Mahindi within the Kagera Park. Mr. B. Cooper, of Tanganyika Game Department, who had been attached to de Beer's party, sent game rangers into the Karagwe to locate mother rhinoceroses with calves at heel.

On the evening of 19th July the capture team reached Karagwe. It consisted of Mr. and Mrs. de Beer, three European assistants from South Africa and a dozen experienced Africans. The equipment comprised : one Dodge power-wagon, more or less armoured; one "pick-up" ; two Ford lorries ; a complete camping outfit and some crates in which to put the rhinos. The next day the operation began.

The fact that Karagwe still has perhaps a hundred black rhinoceros is without doubt due to its almost inaccessible terrain. Valleys and thickly wooded mountain sides provide excellent shelter for these animals, and it is only at the height of the dry season, when the majority of the springs are dried up, that they are forced to take themselves to larger watering places. So Mr. de Beer spent the first few days in reconnoitering the country and it was not until the 30th July that the first capture was made.

\section{The Capture of a Rhinoceros}

Mr. de Beer directs operations at the wheel of his Dodge. On the platform behind him are his assistants. They have a very flexible rod about 3 metres long carrying the noose end of a special rope, $1 \frac{1}{2} \mathrm{~cm}$. in diameter. The other end of this rope is firmly attached to the body of the Dodge.

When a mother rhinoceros and her young are found, the trapper tries by every means in his power, even by bush burning, to drive them on to terrain where the vehicle can get up speed. Then the pursuit begins, for the rhino always take flight unless the young one is too small to follow its mother. As soon as the mother realizes she cannot get away, she stops and charges the vehicle.

It is now that Mr. de Beer, sixty-five years old, shows his great boldness and sang-froid. Aiming to separate the mother from her young one, he circles round the animals, all the while avoiding the furious mother's direct charge, so that only rarely is the car's armoured plating pierced by her horn. Contrary to one's expectations, the mother soon gives up the fight and makes off, deserting her young one. The moment has then come 
to place the vehicle behind the young rhinoceros and to push it several hundred metres so that the mother shall not interfere during actual capture. Then $\mathrm{Mr}$. de Beer drives up close to the animal's flank to enable one of his assistants to place the noose around the head and behind the two horns of the rhinoceros. The car then moves off and, as one end of the rope is firmly attached to it, the captive must follow. As the animal drags at the rope, Mr. de Beer gradually slows down and finally stops. His assistants get down, fasten the animal's limbs together and turn it on its side. If it is not too big they then hoist it into the vehicle and take it back to camp. Otherwise, not without difficulty, they put it into a crate and there it can calm its rage against the solid walls of its cell.

\section{The Captured Rhinoceroses}

The table below gives details of the captured animals.

\begin{tabular}{|c|c|c|c|c|c|}
\hline Name and approximate age & Sex & $\begin{array}{l}\text { Height to } \\
\text { shoulder }\end{array}$ & $\begin{array}{c}\text { Length } \\
\text { Ist }\end{array}$ & $\begin{array}{l}\text { f horns } \\
\text { 2nd }\end{array}$ & $\begin{array}{l}\text { Date of } \\
\text { capture }\end{array}$ \\
\hline $\begin{array}{lcc}\text { Kyerwa } & \cdot & 3 \frac{1}{2} \text { years } \\
\text { Karagwe : } & \cdot & 3 \text { years } \\
\text { Mihindi : } & \text { 15 months } \\
\text { Kadjumbura } & \text {. } 3 \text { years } \\
\text { Bwana Mkubwa } & 4 \frac{1}{2} \text { years } \\
\text { Hago } \quad . \quad & \text { 3 years }\end{array}$ & $\begin{array}{l}\text { F. } \\
\text { F. } \\
\text { M. } \\
\text { M. } \\
\text { F. }\end{array}$ & $\begin{array}{l}\mathrm{m} . \\
1 \cdot 20 \\
1 \cdot 18 \\
0 \cdot 90 \\
1 \cdot 16 \\
1 \cdot 27 \\
1 \cdot 14\end{array}$ & $\begin{array}{l}\mathrm{cm} . \\
14 \\
11 \\
7 \\
13 \\
25 \\
10\end{array}$ & $\begin{array}{l}\mathbf{c m} . \\
\mathbf{5} \\
\mathbf{4} \\
\mathbf{3} \\
\mathbf{5} \\
\mathbf{9} \\
\mathbf{5}\end{array}$ & $\begin{array}{l}1958 \\
\text { 30th July } \\
\text { 3rd August } \\
\text { 31st July } \\
\text { 12th August } \\
\text { 15th August } \\
\text { 24th August }\end{array}$ \\
\hline
\end{tabular}

The three females, Kyerwa, Karagwe and Hago, were kept until 15th September in an enclosure specially made for them and afterwards freed in the National Park. The pair, Bwana Mkubwa and Kadjambura, were only in captivity a few days, time to calm them and transport them by lorry from Karagwe to the Park. The little male, Mihindi, had the privilege of making the journey by boat between Lake Mujunju in Tanganyika and Mihindi, a distance of 40 kilometres. At Mihindi, being too small to face the dangers of the bush, he had to remain in the compound, where unfortunately he died from the aftereffects of an attack of enteritis.

Already a year has passed since the introduction of these animals into the Kagera National Park. In spite of the fact that we only see them rarely, we know that they are still in the region they chose after liberation ; the male Bwana Mkubwa and the females Kadjumbura, Kyerwa and Hago live close together, while the female Karagwe stays more than $10 \mathrm{~km}$. away on one of the "peninsulas" in the park. 


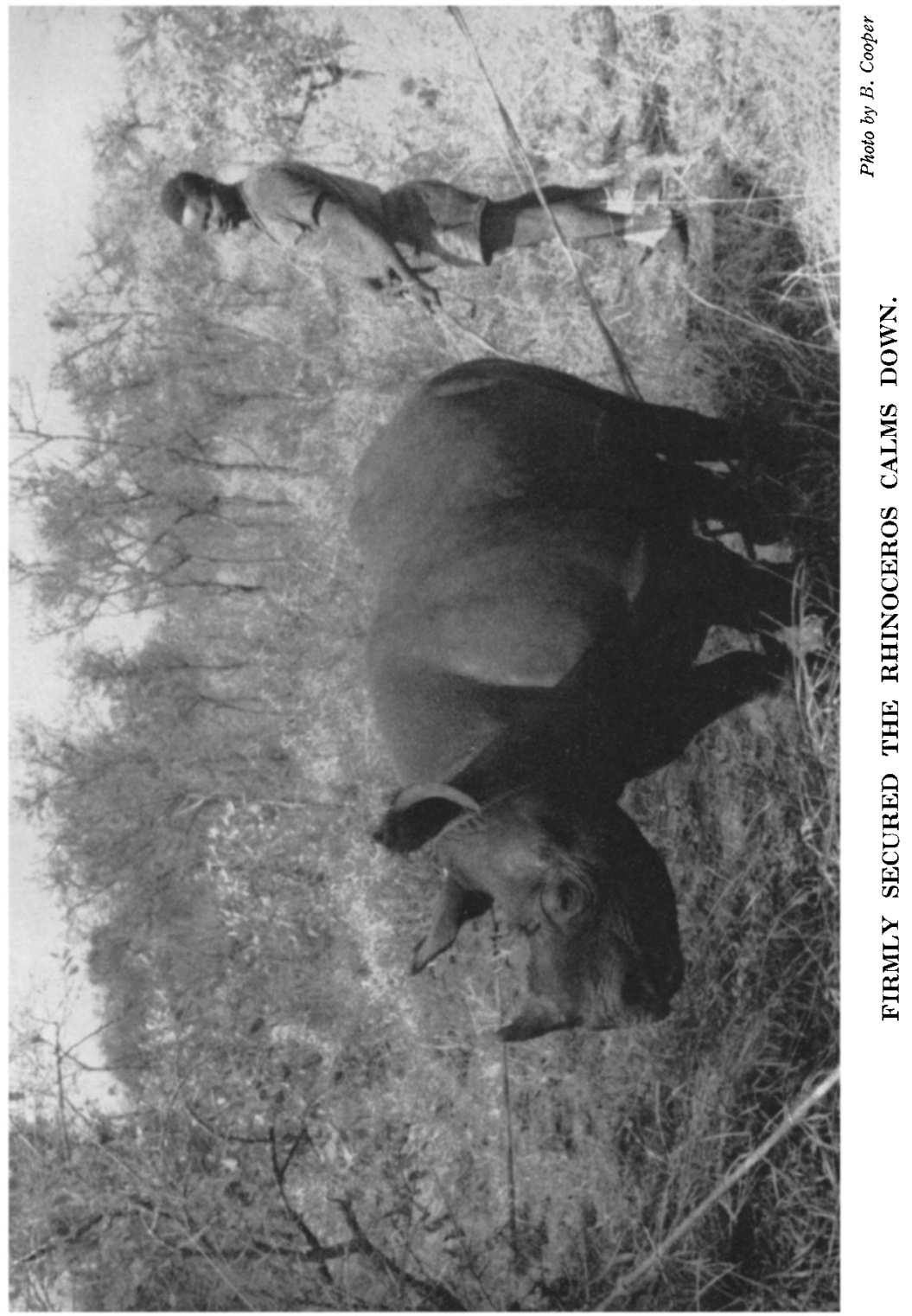




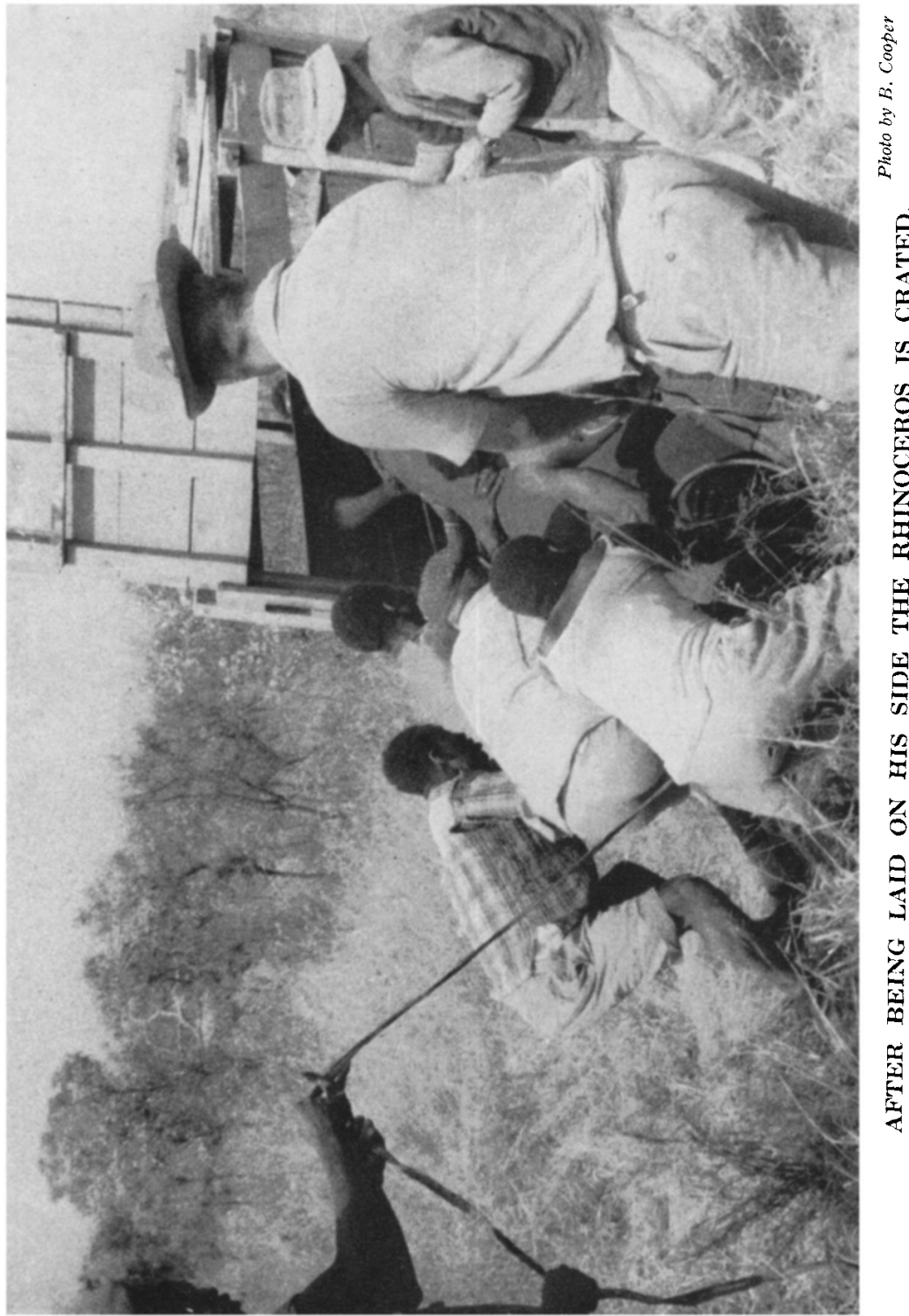




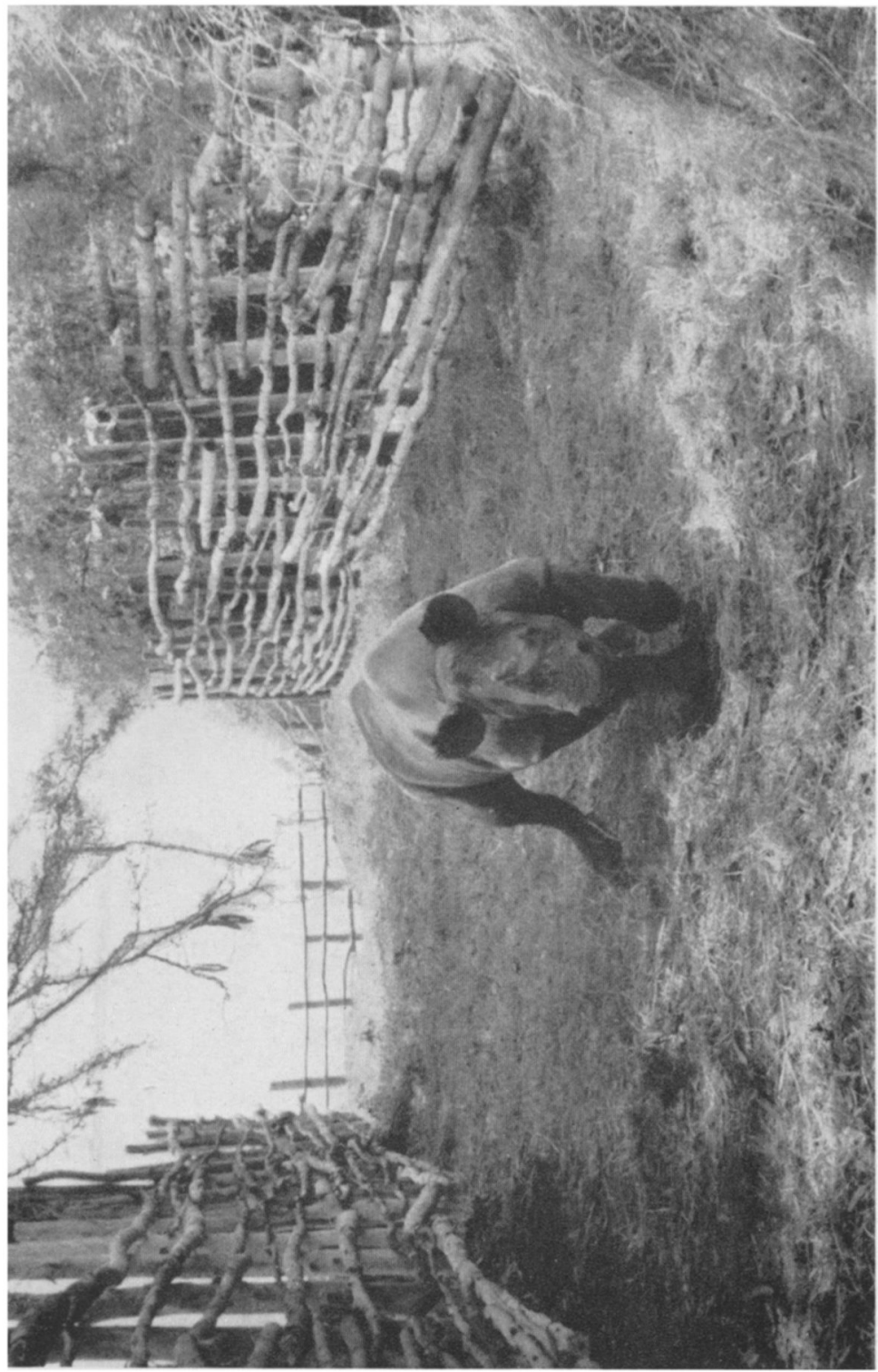

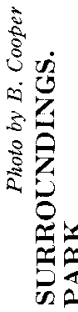

浗

舆

อ글

되닌

8

Z西

焉悬

是国

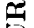

늠

35

3

외롣

고

$-1$

궁ํㅇ

国 
All seem in very good health and full of vitality, which proves that they are well adapted to their new surroundings. During the day they keep to the wooded parts of the mountains, only coming down towards evening to water and feed. Their favourite food seems to consist of tender Acacia seyal and Acacia senegal. Sometimes they like to eat a branch of Euphorbia calicina or Asparagus africanus.

The little Mihindi has been replaced by another male, Rutabari, which Mr. W. de Beer captured, with permission, in Karagwe on 14th August, 1959. This animal is about three years old and $1 \cdot 14 \mathrm{~m}$. high at the withers. His horns are $11 \mathrm{~cm}$. and $5 \mathrm{~cm}$. long. He has been put on the peninsula where he will be able to join Karagwe.

And so thanks to the initiative of the National Parks Institute of the Belgian Congo and the excellent co-operation of the Game Department of Tanganyika, these animals from, so to speak, a past age, have a chance to multiply and live in peace in a domain where they will have nothing to fear from the hand of man. 